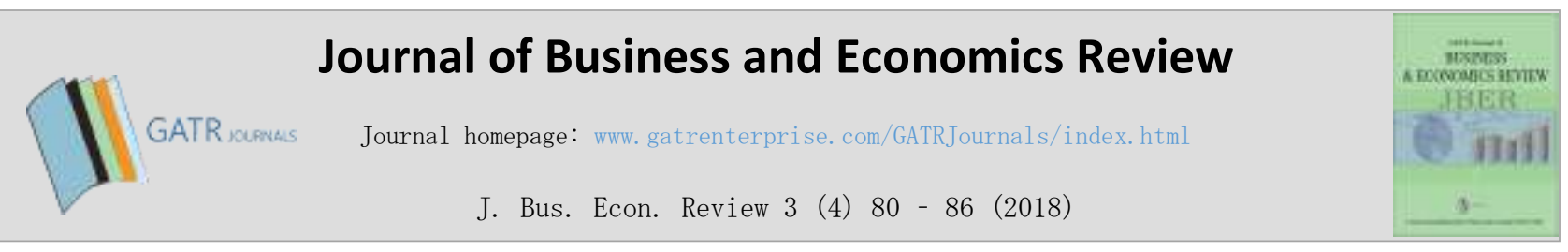

\title{
Granger Causality Between Local Government Expenditure and Economic Growth in Indonesia
}

\author{
Sri Kurniawati \\ Universitas Tanjungpura, Jalan Prof. Dr. Hadari Nawawi, 78115, Pontianak, Indonesia
}

\begin{abstract}
Objective - This study examines the causal relationship between government expenditure and economic growth in West Kalimantan between 2009 and 2015. This research resulted in the enactment of Wagner's Law and/or Keynes's Theory in West Kalimantan leading the local government to take the right policies as an effort towards improving economic development.

Methodology/Technique - By using panel data that combines time series data and cross-site data, it will be estimated by the Granger causality test which begins with a stationary test and co-integration test. Based on the co-integration tests, the results suggest that there is a long-term relationship between government expenditure and economic growth. Meanwhile, based on the Granger causality test, there is no reciprocal relationship between government expenditure and economic growth.
\end{abstract}

Findings - A direct relationship in the form of the influence of government expenditure on economic growth in West Kalimantan.

Novelty - These results are in line with the Keynes's Theory through its national income function.

Type of Paper: Empirical.

Keywords: Government Expenditure; Economic Growth; Co-integration; Causality.

JEL Classification: F40, F43, F49.

\section{Introduction}

The relationship between economic growth and government expenditure is an important subject to be analyzed, particularly whether the public sector increases the economic growth in the long run. In general, government expenditure can increase economic growth. However, financially, government expenditure can have a negative impact on economic growth. First of all, the relationship between government expenditure and economic growth is not consistent; it can be either positive or negative in various countries and regions.

\footnotetext{
* Paper Info: Revised: July 20, 2018

Accepted: December 2, 2018

* Corresponding author: Sri Kurniawati

E-mail: srieniawati@gmail.com

Affiliation: Universitas Tanjungpura, Jalan Prof. Dr. Hadari Nawawi, 78115, Pontianak, Indonesia
} 
Second, the nature of the impact of public spending will depend on certain conditions which can be positive on productive expenditure and negative for unproductive expenditure on economic growth (Barro, 1990). Previous research in this area has identified a two-way relationship between government expenditure and economic growth (Lahirushan \& Gunasekara, 2015; Usman, et al., 2016; Abdieva, et al., 2017), an indirect relationship between economic growth to government expenditure (Biyase \& Zwane, 2015; Boroujli, et al., 2013; Mehrara \& Keshtgar, 2016; Srinivasan, 2013) and an indirect relationship between government expenditure to economic growth (Okoro, 2013; Chiawa, et al., 2012; Ebaidalla, 2013; and Kyissima, 2017). This variation is what motivates the present research to examine the same issue among local governments in Indonesia.

\section{Literature Review}

\subsection{Keynes's Theory}

This research uses the endogenous growth theory which provides the description of the role of government in the process of growth and Wagner's Law. In this theory, the government can influence economic growth both directly and indirectly. Keynes states that government expenditure will increase national income through the following equation: $\mathrm{Y}=\mathrm{C}+\mathrm{I}+\mathrm{G}$, where $\mathrm{Y}$ is national income, $\mathrm{C}$ is consumption expenditure, $\mathrm{I}$ is private expenditure and $\mathrm{G}$ is government expenditure.

Aggregate demand and inflation will decline where there is a decrease in government expenditure and an increase in taxes. Meanwhile, aggregate demand will increase when there is an increase in government spending and a decrease in taxes, which will further increase employment.

\subsection{Wagner's Law}

Wagner's law measures the comparison of government expenditure on national products. Wagner identifies five factors that increase government expenditure: (1) demand for increased security and defense protection, (2) an increase in community income levels, (3) urbanization that accompanies economic growth, (4) the development of democracy, and (5) the inefficiency of bureaucracy that accompanies the development of government (Brons \& Nijkamp, 1999). In other words, Wagner's law is an important instrument that explains the complementary relationship between economic growth in a region with an increase in demand for public services (Arora \& Verma, 2010).

\subsection{Empirical Studies}

The examination of the causal relationship between government expenditure and economic growth provides various results. A positive relationship from government expenditure to economic growth (support for the Keynesian Theory) is reported by Chiawa, et al., (2012), Okoro (2013), Ebaidalla (2013), and Kyissima, et al., (2017). Meanwhile, Zhang \& Zou (2003) and Abu-Daber \& Aamer (2003) report a negative relationship between the two. Further support for Wagner's Law was provided by Biyase \& Zwane (2015), Mehrara \& Keshtgar (2016), Ogbokor (2015), Srinivasan (2013), and Wang \& Dumitrescu (2016). The results of several studies show the existence of a two-way relationship between government expenditure and economic growth as reported by Loizides \& Vamvoukas (2005), Usman, et al., (2016), and Abdieva, et al. (2017).

The causal relationship between government revenue and expenditure occurs in Kyrgyzstan and Tajikistan, however the influence of income on government expenditure is greater than the effect of government expenditure on revenue (Abdieva, et al, 2017). The causal relationship between government expenditure and economic growth also occurred in Nigeria between 1970 to 2010. Economic growth has a positive effect on government expenditure, more specifically capital expenditure, while capital expenditure 
does not affect economic growth. The type of government expenditure that affects Nigeria's economic growth is routine expenditure (Usman, et al., 2016).

Research conducted in Egypt, Britain and Ireland shows different results for the short and long term. Government expenditure causes short-term economic growth in Egypt, Britain and Ireland, but in the long run, it only occurs in Ireland and Britain. Meanwhile, economic growth only leads to increased government expenditure in Egypt. (Loizides \& Vamvoukas, 2005).

\section{Research Methodology}

This research uses secondary data which combines time series (seven years) and cross-sections (14 districts/cities), in the form of government expenditure (GE) and income per capita (EG) of districts/cities in West Kalimantan Province. The data was analyzed using a Granger-causality test. Government expenditure is the total value of government expenditure, while the economic growth employs the logarithm value of income per capita, Both are expressed in Rupiah. Before estimating these two methods, the following steps are taken (described below).

\subsection{Unit Root Test}

The Unit Root Test was conducted to examine the stationary data which contains a coherent element of time through the Augmented Dicky Fuller Test (ADF), described as follows:

$D Y_{i t}=\alpha_{0}+\gamma Y_{i, t-1}+\sum_{i=1}^{\rho} \beta_{i} D Y_{i, t-1+1}+\varepsilon_{i t}$

The stationary data is based on the comparison of statistical values from Mackinnon. If value |ADFstat > Mackinnon critical value, then the data is stationary, and vice versa.

\subsection{Co-integration Test}

A co-integration test was performed to determine the long-term balance between economic growth and government expenditure in West Kalimantan. The criteria for co-integration testing in this study was based on trace statistics. If the trace statistics are greater than the critical value by $5 \%$, then the alternative hypothesis which states that the co-integration number accepted can be determined by how many equations were co-integrated in the system.

\subsection{Granger Causality Test}

The Granger Causality Test was used to examine the relationship of the two variables used. The Granger Causality Test method was described as follows:

$I_{i t}=\sum_{i=1}^{m} a_{i} I_{i, t-i}+\sum_{j=1}^{n} b_{j} Y_{t-j}-\mu_{i t}$

$Y_{i t}=\sum_{i=1}^{r} c_{i} I_{i, t-i}+\sum_{j=1}^{S} b_{j} Y_{t-j}-\varepsilon_{i t}$

$\mu_{i t}$ and $\varepsilon_{i t}$ are an error term that was assumed not to contain serial correlation, and $\mathrm{m}=\mathrm{n}=\mathrm{r}=\mathrm{s}$. To strengthen the indication of the existence of various forms of causality, the F-test must be used for each regression model. 


\section{Results}

\subsection{Root Unit Test Results}

Based on the unit root test at the level of the initial hypothesis (level), economic growth and government expenditure are not stationary. Non-stationary data will result in spurious regression. The results of calculations were as if they were true and statistically significant however they were in fact insignificant. Therefore, the unit root must be tested at the first degree (first difference). Economic growth has a greater ADF value than the value of all McKinnon Critical Values. Similarly, government expenditure has a greater ADF value than the value of the McKinnon Critical Value. Hence, it can be concluded that the two variables were stationary at the first degree level.

Table 1. Result at degree level one (First Difference)

\begin{tabular}{|c|c|c|c|c|c|}
\hline \multirow{2}{*}{ Variable } & \multirow{2}{*}{ ADF value (Prob) } & \multicolumn{2}{|c|}{ Nilai McKinnon Critical Value } & \multirow{2}{*}{ Note } \\
\cline { 3 - 5 } & & $1 \%$ & $5 \%$ & $10 \%$ & \\
\hline EG & $-5,503945(0,0078)$ & $-5,295384$ & $-4,008157$ & $-3,460791$ & Stationary \\
\hline GE & $-7,704253(0,0022)$ & $-5,835186$ & $-4,246503$ & $-3,590496$ & Stationary \\
\hline
\end{tabular}

\subsection{Co-integration Test}

In the Johansen co-integration test, $\mathrm{H} 0$ shows no co-integration while $\mathrm{H} 1$ shows a co-integration. The calculation results indicate the rejection of the initial hypothesis ( $\mathrm{H} 0)$ which means that there is one cointegration equation shown by the number of co-integration as much as one $(r=1)$. Hence, there is a trace statistic value that is greater than the value of the critical value. This means that, in the long run, the two variables have a long-term relationship.

Table 2. Result

\begin{tabular}{|c|c|c|c|c|}
\hline \multicolumn{5}{|c|}{ Unrestricted Co-integration Rank Test (Trace) } \\
\hline Hypothesized & Eigenvalue & $\begin{array}{c}\text { Trace } \\
\text { No. of CE (s) }\end{array}$ & $\begin{array}{c}0.05 \\
\text { Statistic }\end{array}$ & Prob \\
\hline None* & 0.999046 & 50.43385 & 15.49471 & 0.0000 \\
\hline At most 1 & 0.221130 & 1.749375 & 3.841466 & 0.1860 \\
\hline
\end{tabular}

\subsection{Granger Causality Test}

Before conducting the granger test, the optimal amount of lag must be determined by looking at the minimum Schwarz Information Criterion (SIC) through the VAR test. Based on the VAR test, the SIC value of each lag was obtained as follows: 
Table 4. Comparison of the value of lag income per capita and government expenditures

\begin{tabular}{|c|c|c|c|c|c|}
\hline & Lag 0 & Lag 1 & Lag 2 & Lag 3 & Lag 4 \\
\hline Nilai SIC & 28.42725 & 28.57015 & 28.77817 & $28.33957 *$ & 28.51738 \\
\hline
\end{tabular}

* indicates the most optimum lag

The SIC value in the third lag was the smallest value of the comparison of all lags. The calculation of the Granger Causality in this study uses three lags. In addition, the co-integration testing in this study also uses the same lag as in the Granger Causality. In the Granger test, the calculation results are as follows:

Table 5. Calculation results of the Granger causality test

\begin{tabular}{|c|c|c|c|}
\hline Null Hypothesis & F-Statistic & Prob & Not \\
\hline $\mathrm{D}(\mathrm{GE})$ does not Granger Cause D(EG) & 0.53656 & 0.6610 & H0 accepted \\
\hline $\mathrm{D}(\mathrm{EG})$ does not Granger Cause D(GE) & 3.48625 & 0.0283 & H0 rejected \\
\hline
\end{tabular}

The results show that economic growth and government expenditure in West Kalimantan does not have a causal relationship. Only government expenditure to economic growth shows a direct relationship. This means that changes in the value of economic growth were caused by changes in the value of government expenditure in the past, however the reverse is not true.

\section{Discussion}

This research does not prove the existence of reciprocity (causality) between government expenditure and economic growth in the province of West Kalimantan between 2009 and 2015. Instead, it suggests a direct relationship from government expenditure to economic growth. These findings supports the Keynesian Theory which states that in West Kalimantan, the driving force for economic growth is government expenditure. Based on the statistical tests, the result obtained the smallest value in lag 3 . This means that changes in economic growth occurring at this time are the result of changes in government expenditure three years ago. This requires the regional government to continue to make efforts to accelerate economic growth by continuing to increase expenditure every year.

The results of this study are consistent with the findings of Chiawa, et al., (2012), Okoro (2013), Ebaidalla (2013), and Kyissima, et al., (2013) who identified an indirect relationship between government expenditure and economic growth in each region studied. A one-way relationship between government expenditure and economic growth in which government expenditure is an economic function of economic growth at the establishment of the Keynesian theory. This means that policies implemented by the government regarding government expenditure have achieved their goal to accelerate economic growth by strengthening economic resilience.

The implementation of regional autonomy which began in January 2001 for provinciale and district levels contains two important issues. First, the regional autonomy delegates the authority of the central government to regional governments in terms of the administration of government. In addition, it delegates the task of development and management of economic resources which includes extracting sources of revenue and allocation of expenditure in accordance with the needs and priorities of each region.

The regional autonomy policy aims to empower regional capacity to have the opportunity to develop and improve its economy. Increasing regional economic growth will have a positive influence on improving people's welfare in the region. The authority's ability to regulate and prioritize the interests of the community 
which aims to improve the economy according to its conditions, needs and abilities. In addition, it is expected to provide maximum service to economic actors in the regions, at a local, regional, national and global level.

The results of this study demonstrate that there is no (independency) relationship between economic growth and government expenditure. This shows that individuals use their income for consumption activities of imported goods which involves local community relationships with foreign countries, rather than encouraging government activities through their expenditure.

\section{Conclusion}

Based on the results and the analysis of this study, it can be concluded that the movement of government expenditure and economic growth is related with stability or balance and similarity in the long run. In other words, every short-term period, the two variables tend to adjust to each other to achieve long-term equilibrium. The final conclusion of this study is based on the Granger Causality Test and concludes that there is only a direct relationship between government expenditure and economic growth. This shows that in West Kalimantan, Keynes's theory applies where government expenditure influences economic growth.

The following recommendations are made:

It is necessary to increase regional government expenditure in the form of public expenditure for potential sectors that are able to drive the regional economy.

It is necessary to maintain a long-term relationship between government expenditure and economic growth in West Kalimantan so that the activities of local governments can create quality of economic growth.

There must be coordination between the local government and the central government in determining the priority scale for public expenditure, particularly on infrastructure development.

\section{References}

Abdieva, R., Baigonushova, D. and Ganiev, J. (2017). Relationship Between Government Expenditure and Economic Growth in Transition Countries: Case of Kyrgyzstan and Tajikistan. Bilig, 83, 241-258.

Abu-Daber, S. and Aamer S. (2003). Government Expenditure, Military Spending and Economic Growth: Causality Evidence from Egypt, Israel and Syria. http:/ssrn.org/-163.

Arora, R. and Verma, S. (2010). Does the Indian Economy Support Wagner's law? An Econometric Analysis. Eurasian Journal of Business and Economics, 3(5), 77-91.

Barro, R. J. (1990). Government Spending in a Simple Model of Endogenous Growth, Journal of Political Economy, 98(5), 103-125.

Biyase, M. and Zwane, T. (2015). Economic Growth and Government Expenditures in Africa: Panel Data Analysis. Environmental Economics, 6(3), 15-19.

Brons, M. and P. Nijkamp. (1999). Growth Effect of Fiscal Policies. Timbergen Discussion Paper, Amsterdam, Vrije Universiteit.

Chiawa, M. M., Torruam, J. T. and Abur, C.C. (2012). Cointegration and Causality Analysis of Government Expenditure and Economic Growth in Nigeria. International Journal of Scientific and Technology Research, 1(8), 165174.

Ebaidalla, E. M. (2013). Causality Between Government Expenditure and National Income: Evidence from Sudan. Journal of Economic Cooperation and Development, 34(4), 61-67.

Kyissima, K. H., Pacific, Y. K. T. and Ramadhan, A. A. (2017). Government Expenditure and Economic Growth in Tanzania. International Journal of Development and Economic Sustainability, 5(1), 11-22.

Lahirushan, K. P. K. S. and Gunasekara, W. G. V. (2015). The Impact of Government Expenditure on Economic Growth: A Study of Asian Countries. World Academy of Science, Engineering and Technology International Journal of Humanities and Social Science, 9(9), 3152-3160.

Loizides, J. and Vamvoukas, G. (2005). Government Expenditure and Economic Growth: Evidence from Trivariate Causality Testing. Journal of Applied Economics, 8(1), 125-152. 
Mehrara, M. and Keshtger, N. (2016). Government Expenditure and Economic Growth in MENA Region. International Journal of Applied Economic Studies, 4(1), 1-5.

Ogbokor, C. A. (2015). Exploring Co-integration and Causality Relationship Between Government Expenditure and Economic Performance in Namibia. Developing Country Studies, 5(9), 83-91.

Okoro, A.S. (2013). Government Spending and Economic Growth in Nigeria. Global Journal of Management and Business Research Economics and Commerce, 13(5), 20-30.

Srinivasan, P. (2013). Causality Between Public Expenditure and Economic Growth: The Indian case. International Journal of Economics and Management, 7(2), 335-347.

Usman, O., Agbede, E. A. and Bako, H. A. (2016). Integration and Error Correction Modelling. Scientific Research Journal, 4(4), 30-37.

Wang, L., Xu, H. and Dumitrescu, P.A. (2016). The Relationship Between Public Expenditure and Economic Growth in Romania: Does It Obey Wagner's or Keynes's Law? Theoretical and Applied Economics, XXIII (3608), 41-52.

Zhang., \& Zou. (2003). Fiscal decentralization, public spending, and economic growth in China, www.econ. hiu.ac.jp/ kokyo /sympojuly05 /papers/ zhang-China.pdf. 